\title{
The onomatopoeia and your school libraries
}

\author{
Kazuyuki SUNAGA \\ Kokugakuin University \\ 4-10-28 Higashi Shibuya-ku Tokyo 150-8440 \\ Japan \\ sunaga@kokugakuin.ac.jp
}

\begin{abstract}
According to Article 5 in school library law in Japan, a teacher librarian should be posted to the school library. However most of teacher librarians are involved into the other tasks in school so much that they cannot afford to engage school library. The students, who take lesson on school librarianship at university, are less experienced in libraries in school days. Therefore at the beginning of lesson I always try to execute the activity of describing school libraries into onomatopoeias. This activity encourages them to study school librarianship. We will find out the condition, the problems and the challenges of school libraries in Japan.
\end{abstract}

Keywords: Onomatopoeias, Teacher librarian, Training course, Brainstorming

\section{Background}

In Japan, the school library law was enacted in 1953 after the World War II. In the school library law, Article 3 says "All schools should have a school library". While Article 5 says "A teacher librarian (at least) should be posted to the school library", the second schedule had said "A teacher librarian should not be posted to school library for a short period". We had no training course of teacher librarians yet in those days. Besides there were a few teacher librarians with certification. After that, in spite of growing certified teachers gradually, we have less expectation that the condition was improving. According to the second schedule, most of school libraries had been understaffed for approximately 60 years. Exceptionally fulltime teacher librarians were appointed to school libraries. The post of the full-time teacher librarians depended on the local broad of education. One of examples was the high schools in Tokyo.

The school library law was reformed in 1997.All lengthy endeavors of the Japan school library association and other groups had led to the amendment of the school library law. As a result, teacher librarians certificated weren't appointed to schools with more than 12 class rooms until 2003. Thus teacher librarians have been appointed to school libraries since $1^{\text {st }}$ April 2003. Now roughly 20,000 schools nominate teacher librarians. Teacher librarians are appointed in some small schools. However some teacher librarians are reluctant to do their work in school library. Because they teach in their classes so busy and hard that they cannot afford to manage their libraries. If they want to do anything in their libraries, all they do might be open the door and receive their students into library. In contrast some schools assign a school librarian into their library and they work actively. The school librarians aren't required to have qualification of teacher as well as other countries. The activities of school library depend on staffs' effort and the support of headmasters.

So I mentioned above, most of students, who study to be a teacher librarian in university, inconsistently have less experience in school libraries. In the school days they passed, the library often closed. Some of them study hard for the entrance examination of university and others devoted themselves to extracurricular activities in school. In Japan, baseball game and football game are very popular in among of high school students.

I often try to start in using brainstorming with onomatopoeias. At the beginning of lesson and training course of teacher librarian at some universities, students and trainees are 
encouraged to recollect school libraries which they have used. And then they are asked to put their school libraries into particular words, "onomatopoeias".

\section{Example of the lessons}

There are plenty of onomatopoeias in Japanese language. For example, "Niko-Niko" means "smiling happily", "Gera-Gera" means "laughing aloud". Otherwise a dog is barking in "Wan-Wan", a cat is meowing in "Nyaa-Nyaa". Usually we cannot speak to persons and write a sentence without onomatopoeias in Japanese language. Japanese onomatopoeias enable us to widen the range of expressions.

At the beginning of lesson, students are encouraged to come up with onomatopoeias concerned to their school library and put them down notebook in 3 to 5 minutes in the class. And then students are divided into 5 to 3 persons' gropes, talking about their onomatopoeias in 5 minutes. Facilitators are selected in each grope and they will collect the words in each grope. It is like a brainstorming. On behalf of each grope, students pick up them. I collect the onomatopoeias and put them down to the blackboard in classroom.

\section{Bad impression}

Most of students very often use the word "Shiin" to describe their school libraries. This onomatopoeia means silence or soundless. According to the rules, they were always required to be silent in school library. Some students say "Jime-Jime", "Donyori", or "Doyoon". These words mean moisture and humid. In Japan we have a rainy season in June and July. Moreover typhoons often strike Okinawa islands to Honshu, the main island of Japan in August to October. The locked door of school library easily caused to be filled with the humid air in rainy and typhoon seasons. They felt even sticky on the books.

Some students say "Suya-Suya", "Guu-Guu", or "Zuuu". These words mean that someone is napping, deeply sleeping and snoring. Because the atmosphere of school library is always ease and comfortable for themselves. But these words say that there are a few users in school library. "Kotu-Kotu" is the sound of footsteps. "Kari-Kari" sounds that someone is writing with a pencil. Most of students consider a school library as a place to study at the risk of their lives for the entrance examinations of high schools, colleges and universities - now the entrance examinations are not extremely keen, rather to say, it is seemed to be easy to enter a particular university even. "Koso-Koso" is whispering, or that someone keeps acting in secret. These words create, if anything, a bad impression. I mean the bad impression includes a static situation. I would rather to say that school libraries have not been frequently used in Japan. In those days libraries were located in the north side of school building. It was difficult to come to school library for teachers and students. A school library looked like a storage of the books off limited to students. Some school libraries are still not accessible for the staff and students.

\section{Good impression}

Recently I found some words that give a good impression in students' statement in class. For example, "Waku-Waku" means that someone is expecting what is likely to happen. "UkiUki" expresses such feeling as someone is skipping happily. "Honwaka" or "Poka-Poka" sounds warm and heartfelt. These days school libraries are likely to be located in the south or east side of school buildings when the school buildings are designed to be constructed or reformed. "Kira-Kira" has two meaning. They are that the sun or stars shinning and that someone's eyes are sparkling.

"Dokki" expresses shocked or astonished with something. "Doki-Doki" is a heart beating with exiting, expecting, or scaring.

"Wai-Wai" is that students are making some voices chiefly. "Doka-Doka", or "Doya-Doya" are that a big grope of students comes to library at once. "Uro-Uro" is walking around in the library and looking for something. 
"Pera-Pera" has two meanings; the one is turning over the pages of book and the other one is exactly speaking something with fluency but rather chatting with someone. "Pecha-Kucha" has clearly the meaning - chatting with someone.

These words gave us a good impression. I mean the good impression includes a lively situation. I supposed that students came into school library and joined in some activities with their teacher or librarian. The aspect of school libraries is changing gradually. Actually Japanese teacher librarians work so hard in class that they are scarcely involved with their libraries but other teachers and students are likely to use the libraries. I found some activities in these words. It is the evidence that students work in school library.

\section{Other examples}

"Batan" and "Patan" are the sounds of a book falling down on the shelf. "Zuraa" is a scene of books standing on the shelves. "Kichiri" is a scene of books standing neatly. "Guichiri" is a scene of books stuffed without the crevice.

"Pi!" sounds scanning the bar codes on label of book's cover when students borrow book. "Kacha-Kacha" sounds typing a keyboard. However they seldom use computers in their library for other purpose than circulation of materials. Students come to a computer room when they use CD-ROM and DVD-ROM, access to Internet or for information retrieval. School libraries are unlikely to connect with computer room in Japan.

\section{Conclusion}

I think that this programme of describing school libraries with onomatopoeias is popular among of students. They have a very good time at the activity. It brings them back to their libraries in school days and they are talking about their libraries with friends. The onomatopoeias inspires them to start studying on school librarianship more interestingly.

With analysing of these words, we will find out condition, problems and challenges of school libraries in Japan. We know the changes of school libraries in Japan.

\section{References}

Kaida, M. \& Kuroiwa, K. (2007). A Treasure-house of English onomatopoeias. Tokyo: Kenkyusha.

\section{Biographical note}

Professor 2013 to present, Associate Professor (Assistant Professor) 2004-2013, Lecturer 1999-2004 in Kokugakuin University, and Lecturer 1995-1999 in Okinawa International University. University Librarian 1993-1995 in University of library and information science and 1989-1993 in Tsukuba University. MA in library and information science, University of library and information science in Japan, 1989 